\title{
Host shift capability of a specialist seed predator of an invasive plant: roles of competition, population genetics and plant chemistry
}

\author{
M. Tuda* ${ }^{1}$, L.-H. Wu ${ }^{2}$, N. Yamada*3 ${ }^{3}$ C.-P. Wang ${ }^{4}$, W.-J. Wu ${ }^{2}$, S. \\ Buranapanichpan $^{5}$, K. Kagoshima ${ }^{1}$, Z.-Q. Chen $^{6}$, K.K. Teramoto ${ }^{7}$, B.R. \\ Kumashiro $^{7}$, R. Heu ${ }^{7}$ \\ ${ }^{1}$ Institute of Biological Control, Faculty of Agriculture, Kyushu University, \\ Fukuoka 812-8581, Japan \\ ${ }^{2}$ Department of Entomology, National Taiwan University, Taipei 106, Taiwan \\ ${ }^{3}$ Faculty of Agriculture, Kyushu University, Fukuoka 812-8581, Japan \\ ${ }^{4}$ Silviculture Division, Taiwan Forestry Research Institute, Council of \\ Agriculture, Taipei 100, Taiwan \\ ${ }^{5}$ Department of Entomology, Faculty of Agriculture, Chiang Mai University, \\ Chiang Mai 50200, Thailand \\ ${ }^{6}$ Institute of Plant Protection, Yunnan Academy of Agricultural Sciences, \\ Kunming, China \\ ${ }^{7}$ Hawaii Department of Agriculture, 1428 South King St., Honolulu, Hawaii \\ 96814-2512, USA \\ *equal contribution
}

Corresponding author:

M. Tuda

Phone: +81-92-642-3038

FAX: +81-92-642-3040

tuda@grt.kyushu-u.ac.jp 


\begin{abstract}
Acanthoscelides macrophthalmus is a seed predator that has become widely distributed along with its native host, Leucaena leucocephala (Mimosoideae), which is a neotropical leguminous tree and one of the most invasive plants worldwide. Previous studies revealed that $A$. macrophthalmus is able to host-shift to several mimosoid species. Here, we aim to test the hostshift potential to other mimosoid and non-mimosoid plants and possible roles of interspecific competition, genetic background, and plant chemistry in host-shift. First, we found that $A$. macrophthalmus predator completed development on two new hosts: pigeon pea Cajanus cajan and Cajanus scarabaeoides (Faboideae), by rearing from seeds collected in South/Southeast Asia and Hawaii. In contrast, in most regions, both Cajanus species were infested only by other beetle species. Second, we performed no-choice tests using 11 leguminous plants, covering all three subfamilies as potential hosts, including the two new hosts. A Taiwanese A. macrophthalmus population reared in the laboratory on Leucaena did not deposit eggs on any of the seeds of each tested species. To compare host-shift responses between populations, we also used a Hawaiian $A$. macrophthalmus population that had completed its development on freshly collected Leucaena seeds from the field. This population deposited eggs onto and hatching larvae burrowed into $C$. cajan seeds, although none developed beyond the larval stage. Third, the surface chemical composition of seed-pods of L. leucocephala and the two Cajanus species was dissimilar, although that of seeds was highly similar. Finally, all of the host-shifting A. macrophthalmus populations shared the same haplotypic group.
\end{abstract}

\title{
Key words Bruchidae $\cdot$ Biocontrol agent $\cdot$ Phytophagous insect $\cdot$ Ecological
}

fitting $\cdot$ Host range $\cdot$ Hydrocarbon 


\section{Introduction}

Choice of host plants by herbivores shapes plant assemblages and their herbivores. Recent studies show that even specialist (monophagous and oligophagous) herbivorous insects are flexible in their choice of host plants (Messina et al. 2009; Tuda et al. 2009). These findings of host plant flexibility support the ecological fitting hypothesis (Janzen 1985), or phenotypic plasticity, an additional mechanism for coevolution (Ehrlich and Raven 1964), in which evolution of either plant or herbivore species is not a prerequisite (Agosta 2006). Ecological fitting without evolutionary change can promote the expansion of the host range for specialist species (Amarillo-Suarez and Fox 2006; Agosta et al. 2010), which often are considered an evolutionary dead end (Moran 1988). This hypothesis may explain how generalists evolve from specialist lineages (Nosil and Mooers 2005; Kergoat et al. 2007; Kato et al. 2010; Forister et al. 2012).

Ecological and genetic mechanisms behind host shift are yet to be understood (Janz 2011). Examples of factors promoting host-shift are competition among herbivores, phylogenetic closeness of potential hosts, and herbivore's genetic background. Interspecific competition is reduced by host shifts (Feder et al. 1995). Specialist herbivorous insects tend to host shift to plants that are phylogenetically close to their original hosts (Janz and Nylin 1998; Bertheau et al. 2010; Benda et al. 2012). Some genotypes are more adept than others at using new hosts (Tilmon et al. 1998).

Female acceptance of hosts for oviposition is the first important step in the process of host shifts (Jermy 1984), especially for insects in which larvae are more or less sedentary. Both physical and chemical composition of the substrate elicits female oviposition response (Hora and Roessingh 1999; Sulehrie et al. 2003; Gouinguene et al. 2005; Nazzi et al. 2008; Sambaraju and Phillips 2008; Hudaib et al. 2010; Nawrot et al. 2010), and plays an important role in determining the diet breadth and host shift potential of phytophagous insects (Jaenike 1990). Epicuticular waxes of plants, such as alkanes, stimulate oviposition of numerous insect species in the Coleoptera and Lepidoptera (Guerra et al. 1994; Eigenbrode and Espelie 1995; Li and Ishikawa 2006; Nawrot et al. 2010). 
Acanthoscelides macrophthalmus (Schaeffer) (Chrysomelidae: Bruchinae) is a seed predator native to Central America (Kingsolver 2004) that has become widely distributed along with its native host, Leucaena leucocephala (Lam.) de Wit (Fabaceae: Mimosoideae), a neotropical tree and one of the most invasive plants throughout the tropics and subtropics (Lowe et al. 2000). Acanthoscelides macrophthalmus is established in Australia (Raghu et al. 2005), Cyprus (Vassiliou and Papadoulis 2008), Taiwan (Wu et al. 2007; Tuda et al. 2009), southern Vietnam (Kergoat et al. 2005), China (Yunnan), India, Thailand, Japan (Tuda et al. 2009), China (Hong Kong and Hainan), northern Vietnam, and Myanmar (Tuda et al., unpublished data). This insect is oligophagous, feeding only on species belonging to a single genus Leucaena in its native range (Johnson 1979; Hetz and Johnson 1988; Hughes and Johnson 1996; summarized in Tuda et al. 2009). Recently, however, the seed predator was observed attacking Falcataria moluccana (Miq.) Barneby \& Grimes (Mimosoideae), an introduced tree in Taiwan, and potential alternate host (Tuda et al. 2009).

Bruchine seed predators are used as biocontrol agents of weedy plants (Tuda 2007). Acanthoscelides macrophthalmus has the potential to limit the invasiveness of $L$. leucocephala in dry areas where leucaena psyllids are not abundant (Raghu et al. 2005) and was released in South Africa and other African countries to control Leucaena seed dispersal (Olckers 2004). The life history of $A$. macrophthalmus has been studied by Shoba and Olckers (2010), Effowe et al. (2010) and Wu et al. (2012). There have been no reports of host-shifting in these countries and experimental host-shift tests within the plant subfamily (Mimosoideae) have indicated acceptance and development into adults on some species (Shoba and Olckers 2010; Olckers 2011). There is, however, an example of a bruchine beetle (i.e., Bruchidius villosus (F.)) host-shifting to a non-target introduced plant congeneric to the target (Cytisus) (Syrett 1999).

Leucaena leucocephala is a fast-growing nitrogen-fixing tree. However, this multipurpose beneficial tree is, a "conflict-of-interest" plant (Neser 1994) because it excludes plants growing nearby via allelopathy caused by the alkaloid mimosine or leucenol (Mascré 1937; Adams et al. 1945), produced and stored especially in young leaves and mature seeds (Williams and Hoagland 2007). The extract of L. leucocephala also has insecticidal properties (Cavalcante et al. 2006). Seed production of L. leucocephala is heavy and prolific, with 2-4 seed crops 
produced annually (Raghu et al. 2005). Seed dispersal by rodents and birds or through cattle manure, following seed release as pods dehisce, promotes the plants spread throughout adjacent areas (Smith 1985). Leucaena leucocephala has become an aggressive invader in disturbed areas where it was introduced (Walton 2003) and is recognized as one of the worst invasive alien species in the world (Lowe et al. 2000). This plant also promotes the invasion by more aggressive alien plants (Yoshida and Oka 2004).

Seed pods of legumes had been surveyed for possible bruchine infestation (Tuda et al. 2005, 2009) and A. macrophthalmus was found to use not only its original host L. leucocephala and a new host $F$. moluccana (Tuda et al. 2009) but also Cajanus cajan (L.) Millsp. and Cajanus scarabaeoides (L.) Thouars (Fabaceae: Faboideae). Pigeon pea, C. cajan, an erect shrub, is an important crop that is cultivated as an annual or semi-perennial in semi-arid tropical and subtropical farming systems as food, animal feed, and firewood (Shanower et al. 1999). Although approximately $90 \%$ of the world's production of C. cajan is in Asia, this legume also is an important crop in Africa and Latin America. In Hawaii, pigeon peas had been imported and cultivated especially by immigrants from the Philippines. Cajanus scarabaeoides (L.) Thouars, a wild herb, is widely distributed but most abundant on the Indian subcontinent and Australia (Saxena et al. 1990).

Here, we tested the host-shift potential of A. macrophthalmus to phylogenetically distant but confamilial plants. First, by collecting leguminous seeds and rearing larvae, if any, from the seeds in Asia and Hawaii, we investigated host shift events by A. macrophthalmus, along with presence of other seed predator insects. Second, under a no-choice laboratory scenario, 11 leguminous plants were tested, covering all three subfamilies for the first time, as potential new hosts of the seed predator. Two geographic insect populations were used to compare population responses to non-host plants. Third, to test if similarity of plant surface chemicals promoted host-shifts (Parr et al. 1998), surface chemical components were analyzed of seed-pods and seeds of the original, new host, and non-host species. Finally, to test if genetic makeup of the seed predator promoted host-shifts, a mitochondrial region was sequenced of hostshifting and non-host-shifting A. macrophthalmus populations. 


\section{Materials and methods}

\section{The insect and its native host plant}

Two geographic populations of Acanthoscelides macrophthalmus were used for non-choice host shift experiment. One was a mixed population collected in Pingtung County (22.01 N, 120.75 E) and on Hsinchu-Miaoli County border (24.68 N, 120.96 E), Taiwan, in April 2005 (Wu et al. 2013), and the other was a population collected in Hawaii Kai, Oahu, Hawaii, USA (21.31 N, 157.70 W) in February 2011. Acanthoscelides macrophthalmus was first found in Taiwan, Thailand and in Hawaii (on Oahu) in 1995, 1998 (Tuda et al. 2009) and in 1990 (Samuelson 1991), respectively. There have been no attemps of deliberate introduction of A. macrophthalmus for biocontrol in these countries.

Leucaena leucocephala, a native host plant of A. macrophthalmus, has been deliberately introduced to tropical/subtropical regions. Introductions into Asia and a Hawaiian island were as early as the $13-14^{\text {th }}$ century and the $19^{\text {th }}$ century, respectively (Table 1).

\section{Field collection of seeds and rearing}

Cajanus cajan and C. scarabaeoides seeds were collected from various regions from 1995-2011 and reared for possible emergence of the seed predator. Cajanus cajan was collected on Oahu Island, Hawaii, USA (21.39 N, 157.98 W), and Batangas, Luzon Island, the Philippines (13.74 N, $121.09 \mathrm{E})$, and $C$. scarabaeoides was collected in Pingtung County, Taiwan (21.95 N, 120.74 E), Chiang Mai (18.50 N, 98.39 E; 18.41 N, 98.37 E; 18.44 N, 98.68 E), Mae Hong Son (19.29 N, 98.46 E), Lamphun (18.45 N, 99.20 E) and Lampang (17.61 N, 99.23 E) Provinces, Thailand, and in Yunnan Province, China (25.42 N, 101.47 E). The collected seeds from each legume population were kept in a paper bag under semi-natural conditions (Oahu, $17-28^{\circ} \mathrm{C}$; Batangas, $24-32^{\circ} \mathrm{C}$; Yunnan, 8 $23^{\circ} \mathrm{C}$; Taiwan, $11-28^{\circ} \mathrm{C}$; Chiang Mai, $13-31^{\circ} \mathrm{C}$ ) in the country where they were collected. The bags were checked every week for the first 2 months and then every month for 4 additional months. 


\section{No-choice host shift experiment}

Eleven leguminous plants, including the two Cajanus species, were evaluated as potential new hosts of A. macrophthalmus (Table 1). The additional nine species were selected based on phylogenetic closeness to the target, similarity of pod morphology to Leucaena, or dominant abundance in Taiwan. Ten to 15 pairs of adults emerging within $24 \mathrm{~h}$ that had been incubated with Leucaena seeds were paired and put into a $50 \mathrm{ml}$ plastic tube with 30 seeds of one of the legume species. The seeds were replaced with 30 new seeds every day until all of the female A. macrophthalmus died (the sex was determined according to the keys in Wu et al. 2007). This no-choice test for each plant species was replicated three times, and we used the Taiwanese population of A. macrophthalmus for these tests. This experiment was conducted at $27 \pm 1^{\circ} \mathrm{C}, 60 \pm 5 \%$ relative humidity and with 12L:12D photo cycle. These tests were performed in 2007, except for the two Cajanus species, which were completed in 2011.

The Hawaiian A. macrophthalmus population was also used for an additional test. Five pairs of adults emerging within 7 days from field-collected Leucaena seeds were put in a 5.2-cm-diameter Petri dish $(30 \mathrm{ml})$ containing 10 seeds of $C$. cajan. The numbers of hatched and unhatched eggs were counted after all adults had died. This experiment was completed at $20 \pm 2^{\circ} \mathrm{C}, 45 \pm 5 \%$ relative humidity and with 14L:10D. This test was performed in 2011.

\section{Chemical analysis of plant surface}

Surface chemicals (mostly hydrocarbons) were extracted from seed coats of $L$. leucocephala, C. cajan, and C. scarabaeoides, and from seed-pods (pericarp) of L. leucocephala and C. scarabaeoides, by dipping them in ethyl acetate at room temperature. The crude extract was concentrated by purging with nitrogen and resuspended in hexane/ ethyl acetate (10:1). The sample extract was transferred to the column ( $7 \mathrm{~mm}$ i.d.) with $0.7 \mathrm{~g}$ of silica gel (63-210 $\mu \mathrm{m}$ i.d.) and eluted with 5 $\mathrm{ml}$ of hexane : ethyl acetate $(10: 1)$. The eluates were reduced to small volumes by purging with nitrogen.

Gas chromatography-mass spectrometry (GC-MS) was performed for analysis of chemicals on a coupled GC-MS system (GC17A-QP5050A, Shimazu Inc., Kyoto, Japan). The gas chromatograph was equipped with a fused silica 
capillary column (30 m length, $0.25 \mathrm{~mm}$ i.d.) coated with $0.25 \mathrm{~mm}$ of crosslinked poly-dimethylsiloxane (SPB-1, Supelco, Inc., USA). Plant sample extract (1 $\mu \mathrm{l})$ was injected with a splitless injector at $280^{\circ} \mathrm{C}$ (carrier). The gas chromatography oven temperature was maintained at $100^{\circ} \mathrm{C}$ for $3 \mathrm{~min}$, then increased at a rate of $10^{\circ} \mathrm{C} \mathrm{min}^{-1}$ to $30^{\circ} \mathrm{C}$, and held for $17 \mathrm{~min}$, making a total time of $40 \mathrm{~min}$. The interface with the MS was set at $280^{\circ} \mathrm{C}$ and MS performed in full scan mode using $70 \mathrm{eV} \mathrm{EI}^{+}$and scanned from 50 to $400 \mathrm{~m} / \mathrm{z}$ (carrier: helium; flow rate: $0.9 \mathrm{ml} \mathrm{min}$

$\left.{ }^{1}\right)$. Chemical components were identified by comparing peak retention times with those of authentic standards, and by a GC-MS analysis of representative samples. Chemical compositions were measured based on peak areas. Each plant sample extract was analyzed twice. Multivariate correlations of chemical composition between the original and new host plants or non-host plants were estimated with JMP8.0.

\section{DNA analysis}

Crude DNA was extracted from a sample of the 10 beetles (60 total) from the Yunnan, Oahu, Lampang, and Lamphun populations and the Taiwanese laboratory population, all from L. leucocephala and Nantou population from $F$. moluccana (23.75 N, 120.86 E; Tuda et al. 2009) using a DNeasy Tissue Kit (Qiagen, Tokyo, Japan). Amplification of a 522-bp mitochondrial COI region was performed by polymerase chain reaction (PCR) with the primers COI2-1 (Tuda et al. 1995, 2004) and COI2-2 (Tuda et al. 2004) and sequencing followed. For the PCR and sequencing, the protocol previously described in Tuda et al. (2004, 2006) was followed. To estimate a statistical parsimony haplotype network (Templeton et al. 1992), we used TCS 1.21 (Clement et al. 2000) with the connection limit set at $95 \%$.

\section{Results}

Field collection of seeds and beetle emergence

Acanthoscelides macrophthalmus adults emerged from C. cajan seeds collected in an urban garden center on Oahu (Hawaii) and from two populations of $C$. 
scarabaeoides seeds collected from bare ground along roadsides with little vegetation in Yunnan (China) at seed predation rates 0.0070-0.0168 (Table 2). No A. macrophthalmus emerged from C. scarabaeoides seeds collected in other Asian countries or from C. cajan seeds collected in an agricultural experimental field surrounded by a relatively natural environment in Oahu (Table 2). Instead, several species of Callosobruchus beetles (Chrysomelidae: Bruchinae) and apionid weevils (Curculionoidea) emerged at seed predation rates 0.0044-0.0479 (Table 2). These Callosobruchus species all belonged to the chinensis phylogenetic group that is highly associated with Cajaninae, including Cajanus (Tuda et al. 2005, 2006).

\section{No-choice host shift experiment}

In the no-choice test on Cajanus species, the females of the Taiwanese laboratory population of A. macrophthalmus did not deposit eggs on seeds of either species, while depositing $26.4 \pm 13.8$ (mean \pm SE) eggs on L. leucocephala seeds. In contrast, three hatched eggs of the Hawaiian beetle population were confirmed on the seeds of $C$. cajan. However, none of the early instar larvae from the hatched eggs developed into late instar larvae in the seeds. For the other nine leguminous species tested, the Taiwanese A. macrophthalmus did not deposit eggs on any of the seeds.

\section{Chemical analysis of plant surface}

Chemical compositions of the seed surface for the original (L. leucocephala) and novel hosts (C. cajan and C. scarabaeoides) were similar (Table 3a). For the seedpod surface, however, chemical compositions of the original (L. leucocephala), novel hosts (C. scarabaeoides), or non-hosts were not similar (Table 3b). A sesquiterpene caryophyllene was confirmed from the seed-pod of $C$. scarabaeoides. This volatile compound was reported from $C$. cajan leaves (Hartlieb and Rembold 1996; Ogunbinu et al. 2009) and from L. leucocephala (Finlay-Doney and Walter 2005). 


\section{DNA analysis}

In total, 5 haplotypes were identified and separated into two major groups (Fig. 1). All individuals from the Yunnan, Oahu (both host-shifted to Cajanus in the field), Nantou and Taiwanese laboratory populations (host-shifted to Falcataria, in the field and in the laboratory, respectively, Tuda et al. 2009) belonged to the same haplotypic group (Fig. 1). In contrast, individuals from Lampang and Lamphun (not host-shifted) formed another haplotypic group, except for four individuals from Lamphun that belonged to the former (the majority host-shifted) haplotypic group (Fig. 1).

\section{Discussion}

Our experiments showed that although a shift to a new host by a specialist, or an oligophagous herbivorous insect, is difficult, development under natural conditions may allow a shift to a new plant host that is phylogenetically distant from the original host. Host shift by introduced or invading herbivores has been observed in Bruchinae, but the shift is usually within a related plant group (within plant tribes, Syrett 1999; Tuda et al. 2004, 2005; between plant tribes but still within plant subfamily, in A. macrophthalmus, Tuda et al. 2009; from Erythrina to C. cajan in Specularius, Southgate and McFarlane 1979). This is also true for native specialist insects that encountered introduced plants (Bertheau et al. 2010). However, host shifts can be to more distantly related plants such as from Bauhinia reticulata DC. (Caesalpinioideae) to Arachis (Faboideae) by Caryedon (Sembene 2006) and from Acacia (Mimosoideae) to Parkinsonia (Caesalpinioideae) by Stator (Johnson and Siemens 1991).

The results of our field collections and rearing studies to detect seed predators suggest that frequent encounters with plants without encountering competitors may facilitate a host shift (Table 2), supporting the effect of competitors in host shifts (Janzen 1973; Denno et al. 1995; Feder et al. 1995). The longer an original host (see 'Leucaena introduction' in Table 2) or new potential host (see 'status' in Table 2) has been present in a particular area (results of nochoice experiments and field observation, Table 2), the lower the host shift probability. This is probably because the number of phytophagous insects associated with each plant increase through time (Strong 1977) and serve as 
competitors against recently introduced insects. For the laboratory population kept for several years only on the original host, A. macrophthalmus population may have lost preference for low-rank hosts.

Possible cues for accepting Cajanus as a new host in the natural habitat are currently unknown. Pod morphology and size are not similar between Leucaena and Cajanus; smooth, flat, elongate pods for the former and hairy, rotund, short pods for the latter. Seed morphology also is different; flat for the former and spherical for the latter. In terms of the oviposition site for A. macrophthalmus, there may be some common features between the two genera. Acanthoscelides macrophthalmus deposits eggs on Leucaena pods and seeds that are both on the plant and on the ground and tend to prefer those on the ground, although egg mortality does not differ between the two microhabitats (Egli and Olckers 2012). Cajanus scarabaeoides is a non-climbing herb and C. cajan is a shrub, both of which have pods closer to the ground than Leucaena pods on the tree.

The absence of a toxic chemical also may be a factor for Cajanus acceptance: For example, L-canavanine is absent in both Leucaena and Cajanus species (Bell et al. 1978). In contrast, chemical cues for oviposition are unlikely to be the factor promoting these host-shifts. Although chemical components between the original and new host plants were similar for seed surfaces (Table 3a), those for seed-pod surfaces were dissimilar between the original and new hosts (Table 3b). Because the seed-pods of both Cajanus species do not dehisce until they are mature and dry (Smartt 1990; M. Tuda, personal observation), the seed predator probably had little chance to assess seed surface directly before we collected seedpods that had not dehisced yet. We found caryophyllene, a volatile terpene, from the seed-pods of C. scarabaeoides, the new host plant, but not from $L$. leucocephala (Table 3b). There is, however, evidence that L. leucocephala emits caryophyllene, the amount of which depends on the environment (Finlay-Doney and Walter 2005). This compound also is found from C. cajan (Hartlieb and Rembold 1996; Ogunbinu et al. 2009). Therefore, the chemical similarity among the original and new hosts may be higher in nature than was identified in our chemical analysis. Note, however, caryophyllene alone may not be attractive for phytophagous insects. For example, in another study caryophyllene did not attract the Helicoverpa moths but its mixture with other sesquiterpenes acted as an oviposition stimulant (Hartlieb and Rembold 1996). Likewise, caryophyllene 
alone did not influence the behavior of leucaena psyllids (Finlay-Doney and Walter 2005).

Furthermore, the genetic makeup of the herbivorous insect also can be another factor facilitating host shifts (Wassermann 1986; Bernays and Chapman 1994). The populations that host-shifted belonged to the same haplotypic group (Yunnanese, Hawaiian (this study), Nantou and Taiwanese laboratory (Tuda et al. 2009) populations) (Fig. 1). Contribution of the genome of herbivore populations to host-shift tendency is likely at least in the field. Host-shift tendency, however, may be a consequence of other life history traits, such as high fecundity that often leads to indiscriminate oviposition and is likely influenced maternally. Note that the plant species to which herbivores host-shift probably depends on other factors, such as the composition of local species assemblages (Mitter et al. 1991), or more specifically, distance, apparency [abundance (Bernays and Chapman 1994; Yotoko et al. 2005) and history (Strong 1977)], as well as phenological matching with each species. Further work should clarify the relative contributions of genetics and other ecological and environmental factors that influence host shifts.

In conclusion, our study illustrated rare host-shift occurrences of an oligophagous seed predator that had been considered host-specific. This indicates the lability or plasticity of host range even in so-called specialist herbivores. This case study demonstrated that specialists can host shift to phylogenetically distant plants, which is a counter example of phylogenetically constrained pattern of host shifts (Mitter et al. 1991). Therefore, specialists are not evolutionary dead ends and ecological fitting or plasticity may rescue them as demonstrated in this study, which may eventually fuel evolution towards generalists and host races.

Acknowledgments We thank G.A. Samuelson and J. Romero for the identification of $A$. macrophthalmus. We also thank L.-Y. Chou, Y. Tateishi, and C. Niyomdham for partly assisting with the collection and identification of legumes. This study was supported in part by Grant-inAids for Scientific Research from JSPS and by the Research Grant for Young Investigators of Faculty of Agriculture, Kyushu University to MT. This study complies with the current laws of countries in which collection and experiments were performed. 


\section{References}

Adams R, Cristol SJ, Anderson AA, Albert AA (1945) The structure of leucenol, 1. J Amer Chem Soc 67:89-92

Agosta SJ (2006) On ecological fitting, plant-insect associations, herbivore host shifts, and host plant selection. Oikos 114:556-565

Agosta SJ, Janz N, Brooks DR (2010) How specialists can be generalists: resolving the "parasite paradox" and implications for emerging infectious disease. Zoologia 27:151-162

Amarillo-Suarez AR, Fox CW (2006) Population differences in host use by a seed-beetle: local adaptation, phenotypic plasticity and maternal effects. Oecologia 150:247-258

Bell EA, Lackey JA, Polhill RM (1978) Systematic significance of canavanine in the Papilionoideae. Biochem Syst Ecol 6:201-212

Benda N, Possley J, Powell D, Buchanan-McGrath C, Cuda J (2012) New host plant record for the poison ivy sawfly, Arge humeralis (Hymenoptera: Argidae), and its performance on two host plant species. Fl Entomol 95:529-531

Bernays EA, Chapman RF (1994) Host-Plant Selection by Phytophagous Insects. Chapman and Hall, New York, London

Bertheau C, Brockerhoff EG, Roux-Morabito G, Lieutier F, Jactel H (2010) Novel insect-tree associations resulting from accidental and intentional biological 'invasions': a meta-analysis of effects on insect fitness. Ecol Lett 13:506-515

Cavalcante GM, Moreira AFC, Vasconcelos SD (2006) Insecticidal potential of aqueous extracts from arboreous species against whitefly. Pesquisa Agropecuária Bras 41:9-14

Clement M, Posada D, Crandall K (2000) TCS: a computer program to estimate gene genealogies. Mol Ecol 9:1657-1660

Denno RF, McClure MS, Ott JR (1995) Interspecific interactions in phytophagous insects competition reexamined and resurrected. Annu Rev Entomol 40:297-331

Effowe TQ, Amevoin K, Nuto Y, Mondedji D, Glitho IA (2010) Reproductive capacities and development of a seed bruchid beetle, Acanthoscelides macrophthalmus, a potential host for the mass rearing of the parasitoid, Dinarmus basalis. J Insect Sci 10:1-14

Egli D, Olckers T (2012) Oviposition patterns and egg mortality in Acanthoscelides macrophthalmus (Chrysomelidae: Bruchinae), a biological control agent of Leucaena leucocephala (Fabaceae) in South Africa. Afr Entomol 20:111-118

Ehrlich PR, Raven PH(1964) Butterflies and plants: a study in coevolution. Evolution 18:586-608

Eigenbrode SD, Espelie KE (1995) Effects of plant epicuticular lipids on insect herbivores. Annu Rev Entomol 40:171-194

Feder JL, Reynolds K, Go W, Wang EC (1995) Intraspecific and interspecific competition and host race formation in the apple maggot fly, Rhagoletis pomonella (Diptera, Tephritidae). Oecologia 101:416-425

Finlay-Doney M, Walter GH (2005) Discrimination among host plants (Leucaena species and accessions) by the psyllid pest Heteropsylla cubana and implications for understanding resistance. Agric Forest Entomol 7:153-160 
Forister ML, Dyer LA, Singer MS, Stireman JO, Lill JT (2012) Revisiting the evolution of ecological specialization, with emphasis on insect-plant interactions. Ecology 93:981-991

Gouinguene S, Buser, HR, Stadler, E (2005) Host-plant leaf surface compounds influencing oviposition in Delia antique. Chemoecology 15:243-249

Guerra AA, Martinez S, Delrio HS (1994) Natural and synthetic oviposition stimulants for Catolaccus grandis (Burks) females. J Chem Ecol 20:1583-1594

Hartlieb E, Rembold H (1996) Behavioral response of female Helicoverpa (Heliothis) armigera $\mathrm{Hb}$ (Lepidoptera: Noctuidae) moths to synthetic pigeonpea (Cajanus cajan L) kairomone. J Chem Ecol 22:821-837

Hetz M, Johnson CD (1988) Hymenopterous parasites of some bruchid beetles of North and Central America. J Stored Prod Res 24:131-143

Hora KH, Roessingh P (1999) Oviposition in Yponomeuta cagnagellus: the importance of contact cues for host plant acceptance. Physiol Entomol 24: 109-120

Hudaib T, Hayes W, Brown S, Eady PE (2010) Effect of seed moisture content and D-limonene on oviposition decisions of the seed beetle Callosobruchus maculatus. Entomol Exp Appl 137: 120-125

Hughes CE, Johnson CD (1996) New host records and notes on Bruchidae (Coleoptera) from Leucaena Benth. (Leguminosae, Mimosoideae) from Mexico, Central and South America. J Appl Entomol 120:137-141

Jaenike J (1990) Host specialization in phytophagous insects. Annu Rev Ecol Syst 21:243-273

Janz N (2011) Ehrlich and Raven revisited: mechanisms underlying codiversification of plants and enemies. Annu Review Ecol Evol Syst 42: 71-89

Janz N, Nylin S (1998) Butterflies and plants: a phylogenetic study. Evolution 52:486-502

Janzen DH (1973) Host plants as islands. II. competition in evolutionary and contemporary time.

Amer Nat 107:786-790

Janzen DH (1985) On ecological fitting. Oikos 45:308-310

Jermy T (1984) Evolution of insect/host plant relationships. Amer Nat 124: 609-630

Johnson CD (1979) New host records for Acanthoscelides (Coleoptera: Bruchidae). Pan-Pacific Entomol 55:61-71

Johnson CD, Siemens DH (1991) Expanded oviposition range by a seed beetle (Coleoptera, Bruchidae) in proximity to a normal host. Environ Entomol 20:1577-1582

Kato T, Bonet A, Yoshitake H, Romero-Napoles J, Jinbo U, Ito M, Shimada M (2010) Evolution of host utilization patterns in the seed beetle genus Mimosestes Bridwell (Coleoptera: Chrysomelidae: Bruchinae). Mol Phylogenet Evol 55:816-832

Kergoat GJ, Silvain J-F, Buranapanichpan S, Tuda M (2007) When insects help to resolve plant phylogeny: evidence for a paraphyletic genus Acacia from the systematics and host-plant range of their seed-predators. Zoologica Scripta 36:143-152

Kingsolver JM (2004) Handbook of the Bruchidae of the United States and Canada (Insecta, Coleoptera), vol. I. USDA-ARS, Tech Bull 1912

Li G, Ishikawa Y (2006) Leaf epicuticular wax chemicals of the Japanese knotweed Fallopia japonica as oviposition stimulants for Ostrinia latipennis. J Chem Ecol 32:595-604 
Little Jr. EL, Skolmen RG (1989) Common forest trees of Hawaii. USDA Agriculture Handbook 67

Lowe S, Browne M, Boudjelas S, De Poorter M (2000) 100 of the World's Worst Invasive Alien Species: A selection from the Global Invasive Species Database. The Invasive Species Specialist Group (ISSG) a specialist group of the Species Survival Commission (SSC) of the World Conservation Union (IUCN)

Mascré M (1937) Compt rend 204:890

Merrill ED (1921-1926) An enumeration of Philippine flowering plants, vol. 4. Bureau of Science, Manila

Messina FJ, Jones JC, Mendenhall M, Muller A (2009) Genetic modification of host acceptance by a seed beetle, Callosobruchus maculatus (Coleoptera: Bruchidae). Ann Entomol Soc Amer 102:181-188

Mitter C, Farrell B, Futuyma DJ (1991) Phylogenetic studies of insect-plant interactions: insights into the genesis of diversity. TREE 6:290-293

Moran NA (1988) The evolution of host-plant alternation in aphids: evidence for specialization as a dead end. Amer Nat 132:681-706

Nawrot J, Gawlak M, Szafranek J, Szafranek B, Synak E, Warchalewski JR, PiaseckaKwiatkowska D, Blaszczak W, Jelinski T, Fornal J (2010) The effect of wheat grain composition, cuticular lipids and kernel surface microstructure on feeding, egg-laying, and the development of the granary weevil, Sitophilus granarius (L.). J Stored Prod Res 46:133-141

Nazzi F, Vidoni F, Frilli F (2008) Semiochemicals affecting the host-related behaviour of the dry bean beetle Acanthoscelides obtectus (Say). J Stored Prod Res 44:108-114

Neser S (1994) Conflicts of interest? The Leucaena controversy. Plant Prot News S Afr 6:8

Nosil P, Mooers AO (2005) Testing hypotheses about ecological specialization using phylogenetic trees. Evolution 59:2256-2263

Ogunbinu AO, Flamini G, Cioni PL, Adebayo MA, Ogunwande IA (2009) Constituents of Cajanus cajan (L.) Millsp., Moringa oleifera Lam., Heliotropium indicum L. and Bidens pilosa L. from Nigeria. Natur Prod Comm 4:573-578

Olckers T (2004) Targeting emerging weeds for biological control in South Africa: the benefits of halting the spread of alien plants at an early stage of their invasion. S Afr J Sci 100:64-68

Olckers T (2011) Biological control of Leucaena leucocephala (Lam.) de Wit (Fabaceae) in South Africa: a tale of opportunism, seed feeders and unanswered questions. Afr Entomol 19:356365

Parr MJ, Tran BMD, Simmonds MSJ, Kite GC, Credland PF (1998) Influence of some fatty acids on oviposition by the bruchid beetle, Callosobruchus maculatus. J Chem Ecol 24:1577-1593

Raghu S, Wiltshire C, Dhileepan K (2005) Intensity of predispersal seed predation in the invasive legume Leucaena leucocephala is limited by the duration of pod retention. Austral Ecol $30: 310-318$

Sambaraju KR, Phillips TW (2008) Effects of physical and chemical factors on oviposition by Plodia interpunctella (Lepidoptera : Pyralidae). Ann Entomol Soc Am 101: 955-963 
Samuelson GA (1991) Bruchid in koa haole pods-Acanthoscelides macrophthalmus. Hawaiian Entomol Soc Newslett 1:2

Saxena KB, Singh L, Reddy MV, Singh U, Lateef SS, Sharma SB, Remanandan P (1990) Intra species variation in Atylosia scarabaeoides (L.) Benth., a wild relative of pigeonpea (Cajanus cajan (L.) Millsp.). Euphytica 49:185-191

Sembene M (2006) The origin of groundnut infestation by the seed beetle Caryedon serratus (Olivier) (Coleoptera: Bruchidae): Results from cytochrome B and ITS1 gene sequences. J Stored Prod Res 42:97-111

Shanower TG, Romeis J, Minja EM (1999) Insect pests of pigeonpea and their management. Annu Rev Entomol 44:77-96

Shoba Z, Olckers T (2010) Reassessment of the biology and host range of Acanthoscelides macrophthalmus (Chrysomelidae: Bruchinae), a seed feeding beetle released for the biological control of Leucaena leucocephala in South Africa. Afr Entomol 18 Suppl 1:1-9

Smartt J (1990) Grain legumes: evolution and genetic resources. Cambridge University Press, Cambridge, UK, 381 pp.

Smith CW (1985) Impact of Alien Plants on Hawai'i's Native Biota. In: Stone CP, Scott JM (eds) Hawai'i's terrestrial ecosystems: preservation and Management. Cooperative National Park Resources Studies Unit, University of Hawaii, Manoa

Southgate BJ, McFarlane JA (1979) Host records of Specularius species (Coleoptera, Bruchidae) with notes on the infestation of pigeon peas (Cajanus cajan (L.)) by these beetles. East Afr Agric For J 42:219-223

Strong DR (1977) Time and number of herbivore species: pests of sugarcane. Ecology 58:167-175 Sulehrie MAQ, Golob P, Tran BMD, Farrell G (2003) The effect of attributes of Vigna spp. on the bionomics of Callosobruchus maculatus. Entomol Exp Appl 106:159-168

Syrett P (1999) Broom beetle gets taste for tagasaste. Biocontrol News Inform 20:51

Templeton AR, Crandall KA, Sing CF (1992) A cladistic analysis of phenotypic associations with haplotypes inferred from restriction endonuclease mapping and DNA sequence data. III. Cladogram estimation. Genetics 132:619-633

Tilmon KJ, Wood TK, Pesek JD (1998) Genetic variation in performance traits and the potential for host shifts in Enchenopa treehoppers (Homoptera : Membracidae). Ann Entomol Soc Amer 91: 397-403

Tuda M (2007) Applied evolutionary ecology of insects of the subfamily Bruchinae (Coleoptera: Chrysomelidae). Appl Entomol Zool 42:337-346

Tuda M, Chou L-Y, Niyomdham C, Buranapanichpan S, Tateishi Y (2005) Ecological factors associated with pest status in Callosobruchus (Coleoptera: Bruchidae): high host specificity of non-pests to Cajaninae (Fabaceae). J Stored Prod Res 41:31-45

Tuda M, Fukatsu T, Shimada M (1995) Species differentiation of bruchid beetles (Coleoptera: Bruchidae) analyzed by mitochondrial DNA polymorphism. Appl Entomol Zool 30:377-380

Tuda M, Ronn J, Buranapanichpan S, Wasano N, Arnqvist G (2006) Evolutionary diversification of the bean beetle genus Callosobruchus (Coleoptera : Bruchidae): traits associated with stored-product pest status. Mol Ecol 15:3541-3551 
Tuda M, Wasano N, Kondo N, Horng S-B, Chou L-Y, Tateishi Y (2004) Habitat-related mtDNA polymorphism in a stored-bean pest Callosobruchus chinensis (Coleoptera: Bruchidae). Bull Entomol Res 94:75-80

Tuda M, Wu LH, Tateishi Y, Niyomdham C, Buranapanichpan S, Morimoto K, Wu WJ, Wang CP, Chen ZQ, Zhu HY, Zhang YC, Murugan K, Chou LY, Johnson CD (2009) A novel host shift and invaded range of a seed predator, Acanthoscelides macrophthalmus (Coleoptera: Chrysomelidae: Bruchinae), of an invasive weed, Leucaena leucocephala. Entomol Sci 12:1-8 Vassiliou VA, Papadoulis G (2008) First record of Acanthoscelides macrophthalmus (Schaeffer) (Coleoptera: Bruchidae) in Cyprus. Entomol Hellenica 17:52-55

Walton CS (2003) Leucaena (Leucaena leucocephala) in Queensland. Department of Natural Resources and Mines, Queensland

Wasserman SS (1986) Genetic variation in adaptation to foodplants among populations of the southern cowpea weevil, Callosobruchus maculatus: evolution of oviposition preference. Entomol Exp Appl 42:201-212

Williams RD, Hoagland RE (2007) Phytotoxicity of mimosine and albizziine on seed germination and seedling growth of crops and weeds. Allelopathy J 19:423-430

Wu LH, Wang CP, Wu WJ (2012) Description and differentiation of the four larval instars of Acanthoscelides macrophthalmus (Coleoptera: Chrysomelidae: Bruchinae). Ann Entomol Soc Am 105:259-267

Wu LH, Wang CP, Wu WJ (2013) Effects of temperature and adult nutrition on the development of Acanthoscelides macrophthalmus, a natural enemy of an invasive tree, Leucaena leucocephala. Biol Control 65:322-329

Wu LH, Wu WJ, Wang CP, Chen SW (2007) A new record of bruchid beetle from Taiwan (Acanthoscelides macrophthalmus) (Coleoptera: Bruchidae). Plant Prot Bull Taiwan 49:75-80

Wu S-H, Chaw S-M, Rejmanek M (2003) Naturalized Fabaceae (Leguminosae) species in Taiwan: the first approximation. Bot Bull Acad Sinica 44:59-66

Yang J (2000) Primary analysis on utilization and extension of Leucaena leucocephala. South Fodder Column 3:2

Yoshida K, Oka S (2004) Invasion of Leucaena leucocephala and its effects on the native plant community in the Ogasawara (Bonin) Islands. Weed Technol 18: 1371-1375 Suppl. S

Yotoko KSC, Prado PI, Russo CAM, Solferini VN (2005) Testing the trend towards specialization in herbivore-host plant associations using a molecular phylogeny of Tomoplagia (Diptera: Tephritidae). Mol Phylogenet Evol 35:701-711 
Table 1 Leguminous plants used as potential new hosts of Acanthoscelides macrophthalmus, the seed predator of Leucaena, in no-choice tests.

Fabaceae: Mimosoideae

Acacia confusa Merr.

Acacia farnesiana (L.) Willd.

Albizia lebbeck (L.) Benth.

Fabaceae: Caesalpinioideae

Bauhinia variegata $\mathrm{L}$.

Senna tora (L.) Roxb.

Peltophorum pterocarpum (DC.) K. Heyne

Fabaceae: Faboideae

Abrus precatorius L.

Cajanus cajan (L.) Millsp.

Cajanus scarabaeoides (L.) Thouars

Clitoria ternatea $\mathrm{L}$.

Crotalaria similis Hemsl. 
Table 2 Cajanus species collected as potential alternative hosts of Acanthoscelides macrophthalmus and emerging seed predator beetles.

\begin{tabular}{|c|c|c|c|c|c|c|c|c|}
\hline $\begin{array}{l}\text { Host legume } \\
\text { (Cajanus) }\end{array}$ & Site & Time & $\begin{array}{l}\text { St } \\
\text { at } \\
\text { us } \\
1\end{array}$ & $\begin{array}{l}\text { Leucae } \\
\text { na } \\
\text { introdu } \\
\text { ction } \\
\text { (year) }\end{array}$ & Emerging beetles ${ }^{2}$ & $\begin{array}{l}\mathrm{Nu} \\
\text { mbe } \\
\mathrm{r} \text { of } \\
\text { eme } \\
\text { rgin } \\
\mathrm{g} \\
\text { adul } \\
\text { ts }\end{array}$ & $\begin{array}{l}\mathrm{Nu} \\
\text { mbe } \\
\mathrm{r} \text { of } \\
\text { seed } \\
\mathrm{s}\end{array}$ & $\begin{array}{l}\text { Seed } \\
\text { predati } \\
\text { on rate }\end{array}$ \\
\hline Cajanus cajan & $\begin{array}{l}\text { Oahu Is. } \\
1, \\
\text { Hawaii, } \\
\text { USA }\end{array}$ & $\begin{array}{l}\text { Feb., } \\
2003\end{array}$ & I & $\begin{array}{l}\text { 1860s- } \\
\text { early } \\
1880 s *\end{array}$ & $\begin{array}{l}\text { Acanthoscelides } \\
\text { macrophthalmus }\end{array}$ & 2 & 285 & 0.00702 \\
\hline Cajanus cajan & $\begin{array}{l}\text { Oahu Is. } \\
2, \\
\text { Hawaii, } \\
\text { USA }\end{array}$ & $\begin{array}{l}\text { Feb., } \\
2003\end{array}$ & I & $\begin{array}{l}\text { 1860s- } \\
\text { early } \\
1880 \mathrm{~s}\end{array}$ & $\begin{array}{l}\text { Callosobruchus } \\
\text { pulcher }^{\S \S}\end{array}$ & 4 & 906 & 0.00442 \\
\hline Cajanus cajan & $\begin{array}{l}\text { Luzon } \\
\text { Is., } \\
\text { Philippin } \\
\text { es }\end{array}$ & $\begin{array}{l}\text { Oct., } \\
1998\end{array}$ & I & $\begin{array}{l}\text { prior to } \\
1815^{\#}\end{array}$ & $\begin{array}{l}\text { Callosobruchus } \\
\text { pulcher }^{\S \S}\end{array}$ & $\mathrm{NA}^{3}$ & NA & NA \\
\hline $\begin{array}{l}\text { Cajanus } \\
\text { scarabaeoides }\end{array}$ & $\begin{array}{l}\text { Yunnan } \\
\text { 1, China }\end{array}$ & $\begin{array}{l}\text { Oct., } \\
2004\end{array}$ & $\mathrm{U}$ & $\begin{array}{l}\text { after } \\
1961^{\S}\end{array}$ & $\begin{array}{l}\text { Acanthoscelides } \\
\text { macrophthalmus }\end{array}$ & 7 & 416 & 0.0168 \\
\hline $\begin{array}{l}\text { Cajanus } \\
\text { scarabaeoides }\end{array}$ & $\begin{array}{l}\text { Yunnan } \\
2 \text {, China }\end{array}$ & $\begin{array}{l}\text { Nov., } \\
2004\end{array}$ & $\mathrm{U}$ & $\begin{array}{l}\text { after } \\
1961\end{array}$ & $\begin{array}{l}\text { Acanthoscelides } \\
\text { macrophthalmus }\end{array}$ & 5 & 452 & 0.0111 \\
\hline $\begin{array}{l}\text { Cajanus } \\
\text { scarabaeoides }\end{array}$ & $\begin{array}{l}\text { Pingtung, } \\
\text { Taiwan }\end{array}$ & $\begin{array}{l}\text { Nov., } \\
1995\end{array}$ & $\mathrm{~N}$ & $1645^{* *}$ & $\begin{array}{l}\text { Callosobruchus } \\
\text { theobromae }\end{array}$ & 4 & 107 & 0.0374 \\
\hline $\begin{array}{l}\text { Cajanus } \\
\text { scarabaeoides }\end{array}$ & $\begin{array}{l}\text { Lampang } \\
\text { Thailand }\end{array}$ & $\begin{array}{l}\text { Nov., } \\
1998\end{array}$ & $\mathrm{U}$ & $\begin{array}{l}1238- \\
1378^{\# \#}\end{array}$ & $\begin{array}{l}\text { Callosobruchus } \\
\text { theobromae }\end{array}$ & 21 & $\begin{array}{r}116 \\
9\end{array}$ & 0.0180 \\
\hline $\begin{array}{l}\text { Cajanus } \\
\text { scarabaeoides }\end{array}$ & $\begin{array}{l}\text { Chiang } \\
\text { Mai 1, } \\
\text { Thailand }\end{array}$ & $\begin{array}{l}\text { Nov., } \\
2002\end{array}$ & $\mathrm{U}$ & $\begin{array}{l}1238- \\
1378\end{array}$ & $\begin{array}{l}\text { Callosobruchus } \\
\text { theobromae, } C . \\
\text { chinensis, } C . \\
\text { nigripennis }\end{array}$ & 15 & $\begin{array}{r}115 \\
0\end{array}$ & 0.0130 \\
\hline $\begin{array}{l}\text { Cajanus } \\
\text { scarabaeoides }\end{array}$ & $\begin{array}{l}\text { Chiang } \\
\text { Mai 2, } \\
\text { Thailand }\end{array}$ & $\begin{array}{l}\text { Nov., } \\
2002\end{array}$ & $\mathrm{U}$ & $\begin{array}{l}1238- \\
1378\end{array}$ & $\begin{array}{l}\text { Callosobruchus } \\
\text { dolichosi }\end{array}$ & 8 & 510 & 0.0157 \\
\hline $\begin{array}{l}\text { Cajanus } \\
\text { scarabaeoides }\end{array}$ & $\begin{array}{l}\text { Chiang } \\
\text { Mai 3, } \\
\text { Thailand }\end{array}$ & $\begin{array}{l}\text { Dec., } \\
2003\end{array}$ & $\mathrm{U}$ & $\begin{array}{l}1238- \\
1378\end{array}$ & $\begin{array}{l}\text { Callosobruchus } \\
\text { theobromae }\end{array}$ & 12 & $\begin{array}{r}107 \\
8\end{array}$ & 0.0111 \\
\hline $\begin{array}{l}\text { Cajanus } \\
\text { scarabaeoides }\end{array}$ & $\begin{array}{l}\text { Pai, } \\
\text { Thailand }\end{array}$ & $\begin{array}{l}\text { Dec., } \\
2003\end{array}$ & $\mathrm{U}$ & $\begin{array}{l}1238- \\
1378\end{array}$ & $\begin{array}{l}\text { Callosobruchus } \\
\text { nigripennis }\end{array}$ & 10 & 449 & 0.0223 \\
\hline $\begin{array}{l}\text { Cajanus } \\
\text { scarabaeoides }\end{array}$ & $\begin{array}{l}\text { Lamphun } \\
\text { Thailand }\end{array}$ & $\begin{array}{l}\text { Dec., } \\
2003\end{array}$ & $\mathrm{U}$ & $\begin{array}{l}1238- \\
1378\end{array}$ & $\begin{array}{l}\text { Callosobruchus } \\
\text { theobromae, C. } \\
\text { nigripennis }\end{array}$ & 10 & 252 & 0.0397 \\
\hline $\begin{array}{l}\text { Cajanus } \\
\text { scarabaeoides }\end{array}$ & $\begin{array}{l}\text { Chiang } \\
\text { Mai 3, } \\
\text { Thailand }\end{array}$ & $\begin{array}{l}\text { Dec., } \\
2005\end{array}$ & $\mathrm{U}$ & $\begin{array}{l}1238- \\
1378\end{array}$ & $\begin{array}{l}\text { Callosobruchus } \\
\text { theobromae, } C . \\
\text { dolichosi, } C .\end{array}$ & $\begin{array}{l}103 \\
(\mathrm{Cal} \\
\text { loso }\end{array}$ & $\begin{array}{r}215 \\
0\end{array}$ & 0.0479 \\
\hline
\end{tabular}




$\begin{array}{lr}\text { chinensis, } C . & \text { bruc } \\ \text { nigripennis, } C . & \text { hus) } \\ \text { imitator, } & , 1 \\ \text { Apionidae } & \text { (Api } \\ & \text { onid }\end{array}$

ae)

${ }^{1}$ Status of the Cajanus species in the countries where seeds were collected is indicated by I: introduced; N: native; U: unknown (International Legume Database \& Information Service, www.ildis.org)

2 *: Little Jr. and Skolmen (1989), \# Merrill (1921-1926), §: Yang (2000), **: Wu et al. (2003), \#\#: Tuda et al. (2009), §§: Tuda et al. (2005)

${ }^{3}$ Not available 
Table 3 Chemical composition (\%) of (a) seed surface and (b) seed-pod surface of Leucaena leucocephala (the original host plant of Acanthoscelides macrophthalmus), Cajanus cajan and Cajanus scarabaeoides (new host plants), and Albizia lebbeck and Senna tora (non-host plants). -: not detected, NS: $P>0.05, *: P<0.05, * *: P<0.01, * * *: P<0.001$

(a)

\begin{tabular}{lrrrr}
\hline Seed surface & $\begin{array}{c}\text { Retenti } \\
\text { on time } \\
(\mathrm{min})\end{array}$ & $\begin{array}{c}\text { Leucaena } \\
\text { leucoceph } \\
\text { ala }\end{array}$ & $\begin{array}{c}\text { Cajanus } \\
\text { cajan }\end{array}$ & $\begin{array}{c}\text { Cajanus } \\
\text { scarabaeoi } \\
\text { des }\end{array}$ \\
\hline Squalene & 23.8 & 85.3 & 74.5 & 42.2 \\
Nonacosane & 24.5 & 5.3 & 8.1 & 10.1 \\
Hentriacontane & 26.6 & 4.6 & 3.0 & - \\
Heptacosane & 22.8 & - & - & 22.6 \\
a & 25.6 & 4.8 & - & - \\
1-Hexacosanol & 24.3 & - & 8.8 & - \\
b & 26.3 & - & 5.6 & - \\
c & 30.2 & - & - & 10.1 \\
d & 31.4 & - & - & 7.4 \\
e & 32.8 & - & - & 7.5 \\
\hline Correlation & & $1.000^{* * *}$ & $0.987 * * *$ & $0.831^{* *}$ \\
with L. & & & & \\
leucocephala & & & &
\end{tabular}

(b)

\begin{tabular}{|c|c|c|c|c|c|c|}
\hline $\begin{array}{l}\text { Seed-pod } \\
\text { surface }\end{array}$ & $\begin{array}{l}\text { Retenti } \\
\text { on time } \\
(\mathrm{min})\end{array}$ & $\begin{array}{c}\text { Leucaena } \\
\text { leucoceph } \\
\text { ala }\end{array}$ & $\begin{array}{c}\text { Cajanus } \\
\text { cajan }\end{array}$ & $\begin{array}{c}\text { Cajanus } \\
\text { scarabaeoi } \\
\text { des }\end{array}$ & $\begin{array}{l}\text { Albizia } \\
\text { lebbeck }\end{array}$ & $\begin{array}{c}\text { Senna } \\
\text { tora }\end{array}$ \\
\hline Nonacosane & 24.5 & - & 17.1 & 44.4 & 78.7 & 79.6 \\
\hline Hentriacontane & 26.6 & 27.5 & 46.4 & 17.4 & 6.6 & 14.9 \\
\hline Lupenone & 30.2 & - & - & 1.8 & 5.6 & - \\
\hline Caryophyllene & $\begin{array}{r}11.9- \\
12.9\end{array}$ & - & - & 32.2 & - & - \\
\hline Tritriacontane & 29.2 & 52.6 & - & - & - & - \\
\hline Triacontane & 25.4 & - & - & - & - & 1.8 \\
\hline Heptacosane & 22.8 & - & - & 1.6 & - & - \\
\hline $\mathrm{f}$ & $\begin{array}{r}29.4 \& 2 \\
9.8\end{array}$ & 1.1 & 36.5 & 2.6 & 3.5 & 2.8 \\
\hline $\mathrm{g}$ & 31.4 & 18.8 & - & - & - & - \\
\hline Lupenol & 30.5 & - & - & - & 5.6 & - \\
\hline $\mathrm{h}$ & $\begin{array}{r}30.5- \\
30.8\end{array}$ & - & - & - & - & 1.0 \\
\hline $\begin{array}{l}\text { Correlation } \\
\text { with } L \text {. } \\
\text { leucocephala }\end{array}$ & & $1.000 * * *$ & $0.161^{\mathrm{NS}}$ & $-0.128^{\mathrm{NS}}$ & $\begin{array}{r}-0.159 \\
\text { NS }\end{array}$ & $-0.101^{\mathrm{NS}}$ \\
\hline
\end{tabular}


Figure legend

Fig. I Statistical parsimony network of COI sequences of geographic populations of the seed predator, Acanthoscelides macrophthalmus. The size of the pied graph is proportional to the number of individuals. Small blank circles indicate hypothetical haplotypes. 
Fig.1

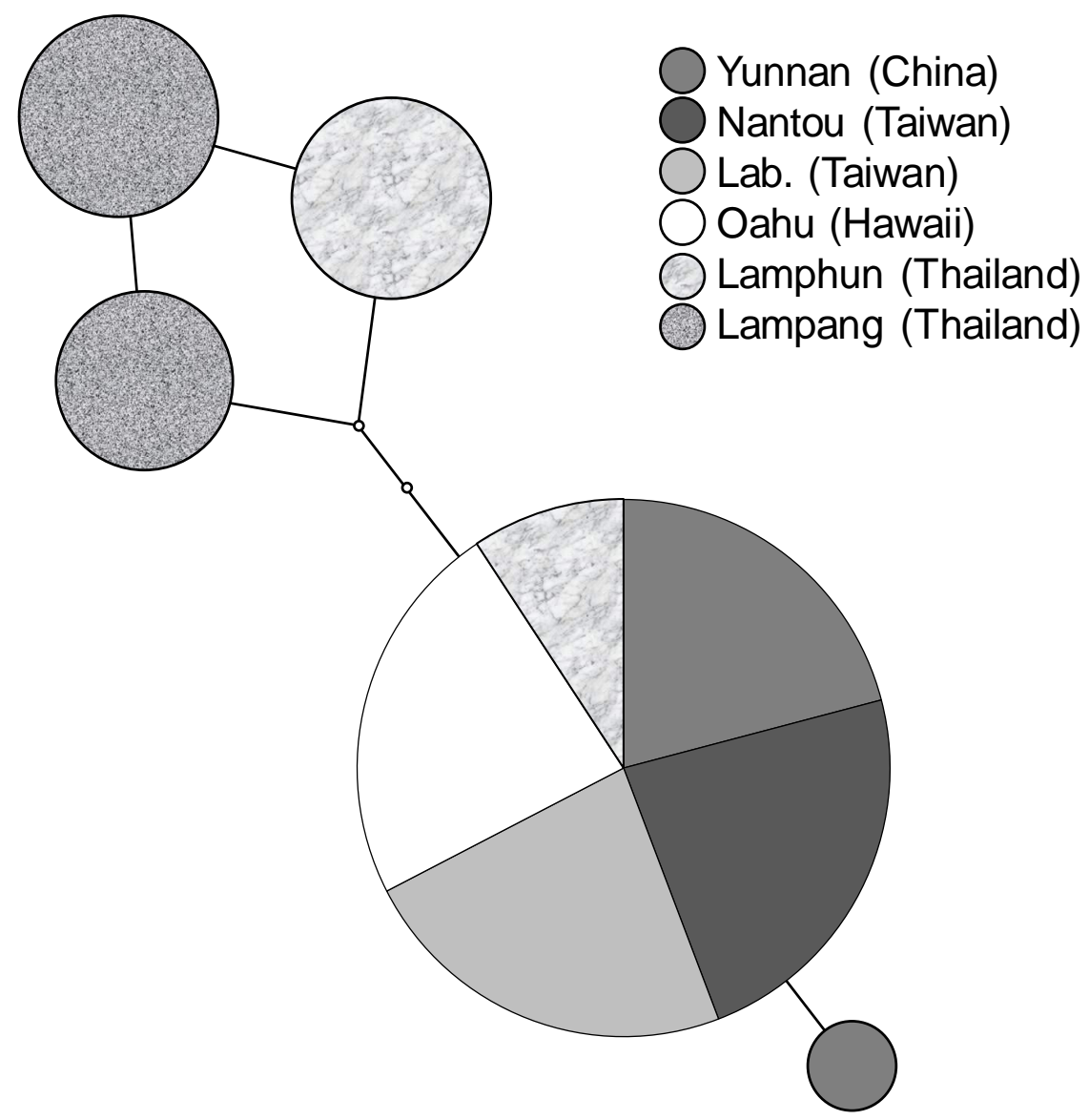




\section{University Library}

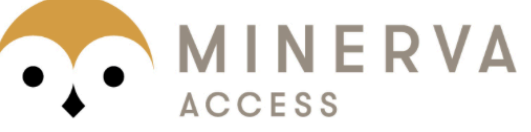

A gateway to Melbourne's research publications

Minerva Access is the Institutional Repository of The University of Melbourne

\section{Author/s:}

Tuda, M;Wu, LH;Yamada, N;Wang, CP;Wu, WJ;Buranapanichpan, S;Kagoshima, K;Chen, ZQ;Teramoto, KK;Kumashiro, BR;Heu, R

Title:

Host shift capability of a specialist seed predator of an invasive plant: Roles of competition, population genetics and plant chemistry

Date:

2014-02-01

Citation:

Tuda, M., Wu, L. H., Yamada, N., Wang, C. P., Wu, W. J., Buranapanichpan, S., Kagoshima, K., Chen, Z. Q., Teramoto, K. K., Kumashiro, B. R. \& Heu, R. (2014). Host shift capability of a specialist seed predator of an invasive plant: Roles of competition, population genetics and plant chemistry. Biological Invasions, 16 (2), pp.303-313. https://doi.org/10.1007/ s10530-013-0519-7.

Persistent Link:

http://hdl.handle.net/11343/282999 